Јелена Љ. Вујић*

Филолошки факултет

Универзитет у Београду
УДК

821.163.41(73).09-1"1941/1990"

ДОИ

https://doi.org/10.18485/analiff.2016.28.2.1

\title{
ПЕСНИШТВО НАДЕ И НОСТАЛГИЈЕ СРПСКЕ ПОРАТНЕ ДИЈАСПОРЕ ${ }^{1}$
}

Овим рефератом се кроз одабир песама представља поетско стваралаштво српске поратне дијаспоре која је углавном стварала у САД и Канади. Њихова поезија (настала од почетка Другог светског рата па до деведесетих година двадесетог века) је прикупљена и недавно објављена у САД у збирци „Нада и носталгија”. Ова песмарица поред дела аматерских песника, бивших официра, логораша, свештених лица и радника садржи и значајне поетске творевине Јована Дучића, Растка Петровића, Владике Николаја Велимировића, Војислава Илића Млађег, Драгутина Рајковића, Милана М. Петровића, Вука Ђуришића, све настале у егзилу. Оно што је заједничко овој поезији јесу снажна, искрена, патриотска осећања и богата симболика везана за српску традицију изнета јаким, лепим, упечатљивим и пажљиво одабраним језичким средствима на чистом српском језику. Иако збирка садржи песме које би се својим уметничким дометом могле сврстати у сам врх српске поезије попут песама „Врбас” и „Босна” Ј. Дучића, које по речима критичара припадају „молитвеном циклусу...као вапај и клетва...” или попут неких непоптуних песама Р. Петровића, има и оних мање вештих аутора. Међутим, оно што је свеприсутно и представља заједнички именитељ за ових седамдесетак песама су меланхоличан тон и непатворена, силна, непреболна чежња и носталгија за родном грудом, том «Чист[ом] Божј[ом] капљ[ом] из заветне чаше..».. Циљ овог реферата је да укаже на поетски допринос песника емиграције српској песничкој баштини 20. века.

Кључне речи: српска дијаспора, родољубива поезија, песнички мотив слободе, дванаестерац, позни отаџбински циклус.

Народ се са ових простора селио и расељавао ношен и шибан вихорима историјских догађаја, природних катастрофа и недаћа. Срби

*_jelenajvujic@gmail.com; jvujic@sbb.rs

1 Делови овог рада су изложени на 45. Међународном сусрету слависта у Вукове дане. 
су се тако расули по свету, па их има на свим меридијанима и по свим ћошковима земаљског шара, где живе, раде и пате за родном грудом. Ту своју носталгију претачу у уметност које се матица ретко сети, а мало је оних стваралаца из расејања који су уврштени у српску културну (књижевну) баштину. У дијаспори су у неком периоду свог живота стварали неки од најславнијих српских књижевника и поета. У овом раду осврћемо се на песничко стваралаштво српске дијаспоре настало од четрдесетих година 20. века у САД када се велики број Срба раселио углавном из политичких, а мање из економских разлога. Жеља нам је да укажемо на мало познато песничко ствралаштво које у сваком случају богати српску песничку баштину, а до данас је било слабо познато.

На то нас подсећа и једна од ретких песмарица са поезијом насталом у дијаспори Haga и ност̄алїија (приређивач др Ранко Симовић) која почиње цитатом Владике Николаја Велимировића «Чувај своју веру и поштуј веру других». Објављена је 2012. године и садржи преко 70 песама, како афирмисаних песника и књижевника попут Николаја Велимировића, Растка Петровића, Војислава Илића Млађег, Јована Дучића, Милана М. Петровића и других, тако и оних који су се песништвом почели бавити као аматери, да би се афирмисали касније у својим срединама. Неки су познати српској књижевној и културној јавности, док су други потпуна непознаница, што не значи да њихова песничка остварења заостају за овим првима. Велики број аутора су бивши заробљеници логора у Оснабрику.

Збирка садржи песме различитог квалитета и уметничких домета али оно што је заједнички именитељ свим песмама, сваком стиху и рими јесу аутентична осећања која преплављују читаоца. Аутори поезију схватају као средство за борбу, за олакшавање бескрајне патње и туге, прозор у наду али и начин да се очувају српско име, вера, језик и обичаји. Свака песма има свога мученика и сваки је мученик пропевао на свој начин. Један од најснажнијих поетских крикова мучеништва и боли на души спевао је Милан М. Петровић у своме «Епитафу».

Каg йуђа рука склойи моје очи, И сииави земљу ӣо ірудима іолим, Ocш̄аће моја gуша gа свеgочи, И йосле смриии колико иее волим. Србијо! 
У последњој речи, том крику је последњи издах, последња мисао свих оних који су живели у туђини и своју неизмерну носталгију, ту рак рану олакшавали мелемом поезије.

Са друге стране, неумирућу наду у повратак је можда најречитије изразио песник Вуко Ђуришић:

Повраииићемо се каg сине иролеће

И одјекну иесме славуја из луїа.

Срияа наша, мајко, заробити неће,

Ни сребро ни злайо- нитии земља gруїа.

Њихов поетски израз је мање-више традиционалне форме, без превише иновација. Прати се модернистичка традиција, што је и разумљиво ако се има увиду да се ради о песницима који су, ако не савременици песника српске модерне, а оно бар васпитавани на њиховом стваралаштву. Модернистички печат се види у строфама које су углавном катрени са схемом риме аабб или абаб, мада има и понека песма са октавом као строфом („Моја мајка», Драгана М. Адамовића) или септимом („Видовдане-молитвени дане», Божидара Л. Ценића). Стих је најчешће дванаестерац, који се показао као најпогоднији за патриотску лирику јер због своје мелодичности и ритмичностии нарочито погодује и за усмено говорење.Такође, дванаестерац се чини најлакшим за савладавање и уклапање јер је у највећој мери ова збирка ипак дело песника аматера који, и поред тога што нису „учени» песници, показују врло коректно владање умећем версификације.

Ову збирку карактерише готово потпуно одсуство љубавне ликрике. Још једна уочиљива особина поезије наде и носталгије јесте да је највећи број песама (готово више од две трећине) писан у директном обраћању песника, било појединцу (најчешће је реч о персонификованој Србији), некој одређеној групи (попут српске омладине) или целом народу (,„Гgе си Слоїо,у времена іорка...», ,Врайићемо се,

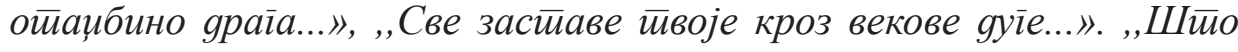
ћуйиш, ћуйиш, о Србине йужни?»). Смењује се прво лице једнине и прво лице множине као лирско ја, док је број песама писаних у трећем лицу готово занемарљив, што се свакако тумачи као директна последица јаког личног печата и исповедајућег тона што је заједничка нит која повезује све ове песме. Читалац се неретко осећа као прималац исповести и слушалац истовремено делећи са песником његова 
најдубља и најинтимнија осећања. О нади и вери у бућност свог рода и Отаџбине говори и чињеница да је много песама писано у императиву и субјунктиву (, Нек йлану сриза ииуна йойла жара...»; „Носи, срйска реко, крв наших синова...»; ,, Мач йламена ваgи- васкрсни у слави!...»; „, Чувај се, мој роgе, својих стиранйуйица»...»; ,ППа gа и мени йеку gани као ирразници-...»; ,ДДа ров свој избавиш о м мука и иииранстива...»).

Неке су песме пригодне са претежно родољубивим и/или политичким набојем. Њихови аутори изражавају своје ставове и осећања према отаџбини, али и оданост одређеним идејама, које из ове перспективе и са ове временске дистанце не морају свима да годе и да се свиде.

Централне теме и мотиви су слобода и патриотизам, певање у част славе и слободарства и величање српске историје. Поред већ поменутог „Епитафа» истичу се „Моје вјерују» и „Српски ветерани» Родољуба Илића, „Рањена Србија» Милана Петровића као и „Песма Светој Србији» Владике Николаја Велимировића. О патриотској лирици Јована Дучића биће посебно речи у наставку овог рада.

Србијо, верујем у йвоје сиирйљење:

У яуховни усйон, борбеносии gа јача,

Верујем у срӣсиива коначно сйасене,

Og окова йуђих и йройасйи мача!

$$
\text { „Mоје вјеруjу» }
$$

Земљо наших ӣраойащуа,

Витезова и светиай,

За крсти часни мученика

За слобояу йоборника.

...Ту Косово йужно стиоји,

Пейвековно ройсивво броји,

Сйомен славе и јунашиива

И неслоіе и издајстива.

$$
\text { „Песма Светој Србији» }
$$

Врло заступљени су фоклорни и етно-мотиви, а значајан део песаа су празничне песме. У том смислу Божић је најчешћи празник о 
коме се пева. Следеће песме су са тематиком Божића: „Бадње вече» Драгана Рајковића, „На Божић» јереја Родољуба Ж. Илића, „На Божић код Веронике» Вуке Ђуришића, „Христос се роди!», „Божић» Исаије Митровића и „Божић-Љубав- Слога» Мирка Божића. У стиховима се углавном позива на мир, слогу, љубав или су инспирација осећања и амбијент Божића далеко од родне груде.

Али ја сам своју срећу изїубио :

Осйао сам давно без свої рояної краја.

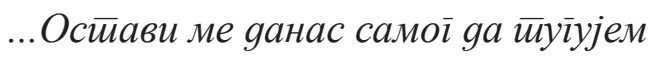

И судбину своїа рояа ойлакујем...

Чуј с храмова наших како брује звона

У славу Госйоgа шйо међ' syge goђе,...

В . Ђуришић „На Божић код Веронике»

Нарочито упечатљива песма „Бадње вече - На риви Ки Веста» Д. Рајковића се од осталих песама у славу Божића разликује како по одабиру песничких слика, тако и по форми. У структури и форми приметни су трагови постмодернизма. ${ }^{2}$ У двадесет седам стихова неједнаке дужине (варира се четрнаестерац, петнаестерац, осмерац, шеснаестерац) филозофски мотиви универзалног свевременског мира и детиње невиности уочи рођења богомладенца се смењују са песниковом интроспекцијом ( Како мисао тионе, У безсвести космичких иемма!). Све то је уклопљено са елементима пезјажа тропског карипског острва (прохладна пучина, кеј, звезадама обасуто небо, мангов грм, кућа Ернеста Хемингвеја), тако другачијег од српског божићњег духа и амбијента.

О дивно Баяне вече!

Са краја ової йуйа као са ивице светиа,

Све ми се чини јеуно -и небо, и земља, и море

2 Рајковић је један од малобројних песника чија су се дела нашла у збирци

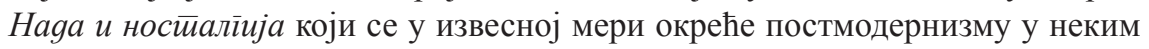
својим песмама као што су „Бадње вече - На риви Ки Веста» и „Одмор», мада је то видљивије у форми него у садржају и тематици. 
И милијарgе свейала оg јеgної gо gруїої ӣола,

Шйо бескрајима іоре.

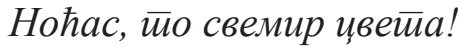

А кая са дахом јуйра звезяаних свейова нестиа,

Зайекла ме зора далеко оg мої сйана,

Крај јеgної манїової ірма на риви Ки Весӣа-

Ко gете очарана.

„Бадње вече - На риви Ки Веста»

Значајно место у тематици заузимају и Косово и косовски мит. Као и све остале и ове песме варирају по квалитету у зависности од вештине аутора, но својом снагом истиче се потресна „Преорали су гробље»Д. Рајковића.

С иррвим бојама зоре йо замаїљеној йрави

Ходи ирилика чудна као gа майлом йлови;

Шамија и ирнина, йоїлеg уїарак йрави, А завежљај у руции свакоїа јуйра нови.

Добри сусеgи кажу већ неgељама луйа:

То јеgинииу тиражи. Очи је исйлакала

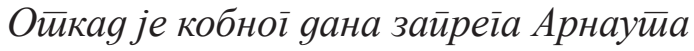

Хумку вољене кћери иреорала.

„Преорали су гробље»

Са истом тематиком су и „Косовка девојка» и „Косовска веридба» М. Петровића које се заснивају на косовској иконографији и предању (Косовка девојка и Топлица Милан), као и „Видовдане-молитвени дане» Б. Л. Ценића, „Данас» Драгана Манчића.

Често се пева о Христу и његовим страдањима која се неретко поистовећују са историјским страдањима српског народа, док се православље изједначава са српством и представља отелотоворење српства и српског духа и суштине. Ови се мотиви између осталих налазе у песмама „Слободи» Р. Илића. „Молитва за Ускрс» М . Петровића.

Ми чекамо иеебе, сву у сјају gела

Вечне Божје йравgе, йобеgнице зала, 
ПЕСНИШТВО НАДЕ И НОСТАЛГИЈЕ СРПСКЕ ПОРАТНЕ ДИЈАСПОРЕ

Да нам иирнов венач расилетеиеш са чела

Твориа рука кая нас буgе васкресала;

Србин кая се gиїне, вечно Боїу оgан,

Као Хрисйос Јудом и изяан и ирован.

„Слободи», Р. Илић

Нежни стихови испевани су и родном крају и лепотама Србије у песмама „Звезда над Врачаром», „Одмор», Д. Рајковића, „Једна ноћ у Живаници» и «,,У Великом Поморављу» Ж. Дамјановића.

O, у Моравскоме мају,

ìgе свакој сииойи юиве

Боїови gа се gиве,

Јер личе на оне у рају.

У йойлом мајском суниу,

Свечано рухо иролећа,

Нуяи вам своје најбоље

Вежено оg биља и иявећа

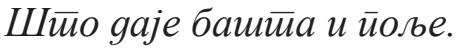

...Пољем се житио йовија

Каgа їа йоїлаgе зефири

И жешиву све иенже чека

Док овgе и оняе ировири

Црвена круна кукурека.

„У Великом Поморављу»

Дамјановићева песма је донекле у ерићевском маниру, врви од пејсажа, боја и звукова. Деветерцом у строфама неједнаке дужине ${ }^{3}$ је постигнута динамика и лакоћа стиха.

Известан број песама посвећен је одређеним личностима (,Генералу Милану Недићу», Драгољуба Манчића, „У српској ноћи - сенима ген. Михајловића», Д. Рајковића).

3 Углавном су строфе катрени али песник се не устеже да уметне и пети стих у строфу у случају када му је он потребан да заокружи песничку слику. 
Филозофски мотиви се јављају у поезији Д. Рајковића (већ поменуте песме „Одмор» и „Бадње вече») са честим реминисценцијама и контемплацији о младости. Живаљ Дамјановић размишља о неким универзалним мотивима као што је циркуларни циклус живота „Вечито се руши и вечито гради» или „Човек и принципи».

Прирояне се силе никаg не нишӣе, Ал'местио и време скуйа исључују:

Узалуд у йоноћ зору сунце ишие ,

Или ловци йлоgне йлиме ӣоручују.

„Вечито се руши и вечито гради»

О пролазности живота размишља и пева и Драган Адамовић у песми „Старост».

Као што се види мотиви и инспирација за поезију налажени су свуда и у сваком, ма како малом детаљу и подсећању на Отаџбину и свој род и народ. У најбројнијим родољубивим песмама има и ставова и порука које се неће свима допасти, али се не могу пренебрегнути емоције изнете у песми „Издајницима Хрватима !» Војислава Илића Млађег написане 1941. ${ }^{4}$

Ко нашом невином крвљу залива юиве наше?

Ко свешиенике коље и иркве наше йали?

Ко расиетиој Србији ириноси оййа чаше?

Ко су йо: Хуни , Готии, Авари или Вандали?

...О нису, авај, нису вравари некулитурни

Већ синови Хрвайске "Куличурне и иросвећене!"

... И каgа црноме робу окове расковасмо,

Браћом их назвасмо својом...

...Не, не, ми нисмо браћа, ми нисмо крв истее крви,

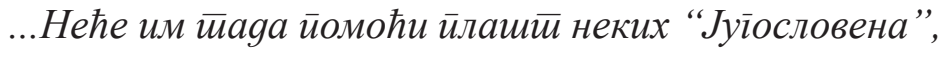

Досйа смо gуїо іајили на свом сриу змију,...

4 Врло слична по тону и поетским сликама је и песма Јована Дучића „Сину тисућљетне културе», написана 1942. 
Из разумљивих разлога, уследполитичке ангажованости и крајње неусклађености са политиком југословенства и братства и јединства као и због изузетно наглашених србо-националних елемената ова песма је мало позната српској читалачкој публици у матици. Са друге стране, она међу нашом дијаспором има веома значајно место и ужива огроман углед заједно са Дучићевом песмом „Врбас”. У обе песме су артикулисана колективна осећања бола и неправде због масакра над српским живљем која су наши људи имали у тим тренуцима почетком Другог светског рата, без обзира да ли су се налазили у Отаџбини, логорима широм Европе или у челичанама Питсбурга и Герија.

Војислав Илић Млађи у петнаест катрена, стихом неједнаке метрике, варирајући четрнаестерац и петнаестерац уз повремени излет у краћи стих (осмерац) испевава ламент разочарења и огорчености због издаје и злочина сународника „братског” народа. При том подсећа и себе и читаоце на велике историјске подвиге српских владара и народа. Како ове стихове не ниже песник, већ његов бес и очај, језик је пренапрегнут емоцијама, израз јак са пуно узвика, вапаја, јадања, па и клетве и претње, али и ироније и метафоре. Сигурно је да ово поетско остварење Војислава Илића Млађег, које осликава и одражава острашћене емоције и климу турбулентних времена у којима је настало, ниједног читаоца неће оставити равнодушним, било да ће изазвати позитивне или негативне импресије. ${ }^{5}$

У исто време, о истим догађајима далеко преко Атлантског океана у егзилу Јован Дучић пише свој „молитвени циклус”, како га је назвао Александар Петров. Најпотресније песме о страдању Срба у Босни и Хрватској („,Врбас”, „Босна”, „Лички мученици”, „На обали Неретве”, „Вечној Србији”) објављене су у листу Американски Србобран 6 . Овај циклус, који се у критици назива још и касним отаџбинским циклусом, по речима Петрова (Симовић 2012:6) није „химнички... није поклич, него плач, није писан на брду и у славу царства на врхунцу моћи, него са дна јаме, као вапај и клетва у име кланих и недокланих...» Песме

5 Одлуком да у рад уврсти песму Војислава Илића Млађег, аутор овог рада не жели никога да увреди, нити да имплицира било каква осећања или оцењује политичку коретност песме и њеног аутора. Песма служи само у илустративне сврхе како бисмо указали на разноврсност и разноликост поезије српске дијаспоре. Добрим делом током 1941. године Американски Србобран је најстарији српски лист, јер је београдска Полиииика престала да излази од почетка Другог светског рата (Петров, 1994). 
касног отаџбинског циклуса пише искусни дипломата, зрео уметник и човек који је спознао и искусио штошта. Његову позну патриотску лирику зато одликује не толико старозаветно, библијско, не осветничко колико мученичко, јеванђеоско и светосавско.

Познате су речи које је о песми „Врбас» изрекао Слободан Јовановић (Симовић 2012:6):

„Његова песма «Врбас», испевана поводом покоља Срба у Босни, бићезабележена у свакој антологији нашег патриотског песништва исто онако као Змајева „Вила», Јакшићево „Падајте, Браћо», Војислављево „На Вардару», Ракићево „На Газиместану»...У данима великог српског страдања и мучеништва Дучић је нашао речи које су могле бити мелем народном болу».

Песма је испевана 20.10.1941, а већ 27.10.1941. објављена је у Американском Србобрану. Ова песма већ деценијама има посебан значај међу српском дијаспором, првенствено због свог тона којим се истовремено изражава неописив бол и жалост који поје над мртвима али и пркос и стоички отпор као и вера у божију правду што нарочито кулминира у последње две строфе.

Беше йаgа славна, а саgа си светиа,

Певај сва крвава кроз юиве и луїе.

Наша звезgа славе саg и gаље извети:

Пре свачији сужюи неї' ичије слуїе.

Носи мора крви gа их не иокраяу,

Носи реко срйска, крв невиних жрйви:

Раgосне йобеgе хероји нам gаgу,

Али ситрашну йравяу извојују мрииви.

„Врбас»

Као и већина ранијих Дучићевих патриотских песама и „Врбас» је писан у дванаестерцу, због чега је неки критичари не сврставају у најбољу Дучићеву каснију лирику. И поред несумњиве лепоте и величине, осећа се на кратак моменат пад и клише (нпр. у „Раgосне йобеge, хероји нам gagy») те смо стога слободни сложити се са констатацијом појединих критичара (Петров 1994: 56) да је Дучић дале- 
ко експресивнији и јединственији али и ,приснији, непосреднији и уверљивији у десетерцу или тринаестерцу, којим је написана његова изванредна песма „На обали Неретве». Уосталом, Дучић јесте своје врхунце досегао и краћем метру, деветерцу, несиметричном осмерцу или седмерцу.»

Позне отаџбинске песме, а песмарица Haga и ностиалїија садржи следећих шест Дучићевих песама:,, Врбас», „Лички мученици», „Босна», „На царев Аранђеловдан», „Вечној Србији», „На обали Неретве», писане су стихом различитог метра. „Врбас», „Вечној Србији» и «Босна» су у дванаестерцу, „Лички мученици» у десетерцу, „На обали Неретве» у тринаестерцу, а „На царев Аранђеловдан» у асиметричном деветерцу. Може се_претпоставити да је оваква шароликост у метрици последица песникове жеље да пронађе прави и најодговарајући стих, да изрази најдубља и најболнија осећања сапатње са својим народом али и своју патњу због егзила у ком се нашао. Такође, разлика у дужини стиха је и разлика у томе која је емоција доминирала у тренутку надахнућа, да ли је реч о посмртном лелеку, пркосу („На обали Неретве»), молитви или разочарању (,На царев Аранђеловдан»).

За йвоју Славу свейли Царе,

Царе наg ирима морима!

Зли жреци яанас иричести кваре;

Губа је у свим иторима...

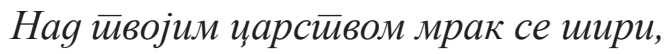

Ветирови ирни яувају:

Саg нашу савести бране жбири

Луиежи блаїо чувају.

„На царев Аранђеловдан»

У том смислу метричке неуравнотежености позне отаџбинске песме, које нису сакупљене и штампане као посебан циклус, по мишљењу Петрова подсећају на песме ,Лирике».

Једна од последњих Дучићевих песама из позног отаџбинског цилуса је,Вечној Србији», постхумно штампана у Американском Србобрану 27. јуна 1944. Остарели песник се пред крај живота, бистрог ума и бритког језика директно обраћа свом народу и Отаџбини. У 
овом случају дванаестерац одговара жељеном ритму који се ка крају песме убрзава јер се нижу снажније и снажније песничке слике да би се у последњој строфи смирио. Дванаестерац даје темпо стиху и целој песми и ствара молитвену интонацију ( у средишњем делу песма готово личи на молитву која се изговара у трансу) .

Застиаву ияеје у руици йоgлацฺа!

Местио мач ийо свейли, увек нож ийо йара!

Бориа шито се блайом местио койља баича,

Јунака шимо йльачка и жреца шито хара!

Засйаву у срамни злочин замочену;

Слобояу у сении йуђих бајонетиа;

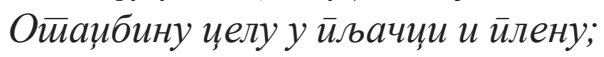

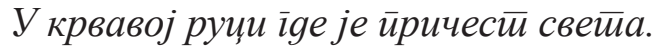

Презри љубав ӣоgлих и брайсииво убица.

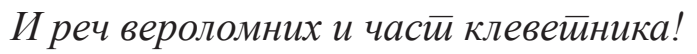

Носи, роде славни, ииај мач без корица-

Знамен крсиионосиа и Божјеї војника!

$$
\text { „Вечној Србији» }
$$

Растко Петровић је такође још један од добро афирмисаних књижевних ствралаца који је стварао у егзилу па су због тога грагменти његове лирике нашли своје место у збирци Haga и носйалїија. Петровића је Други светски рат затекао на позицији вицеконзула у Чикагу, да би касније прешао у Вашингтон на место секретара Посланства Краљевине Југославије. Остао је да лежи у туђини ${ }^{7}$, сахрањен неожаљено на гробљу у Сеновитом Потоку 1949. Његова изгнаничка поезија је наглашено сетна, мелахонлична инспирисана пролазношћу и злом изгнаничком судбином. Стихови и строфе су неједнаке дужине, а доминирају поетске слике самоће и неких безнадежно недостижних

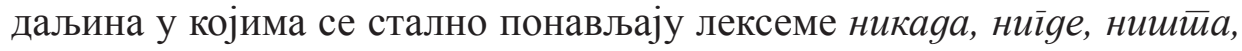
нема којима се негира материјално, временско и просторно постојање,

7 Посмртни остаци Растка Петровића су 1986. године пренети и положени у породичну гробницу Петровића на Новом гробљу у Београду. 
што је рефлексија песникове боли што му је онемогућено да се врати у отаџбину.

Млаяостии ме мину, мила млаяостии моја,

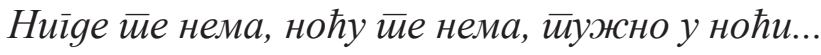

Caga је све іотиово.

Никаgа више и нишӣа више

Никаgа више наgа

Да ћу своје уморно срие йоложити у ваше руке

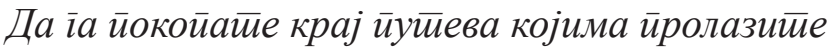

У вечери, заірљени, са својим женама, насмешени

на једно даље йоколење

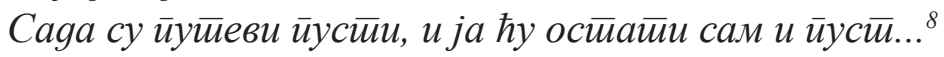

Поезија објављена у збирци „Наgа и носйаліија» је израз јада, борбе за опстанак у далекој туђини како за време рата тако и у поратним годинама. Песме су оригинални и непатворени вапај за родном грудом, оивичене сетом чак и када одишу врцавошћу и лакоћом. Све заједно чине антологију још једне голготе и имигрантске туге непролазне о којој су сви аутори као сужњи певали у хору. То су аутори за које је Отаџбина била мајка и «Чисйа божја кайљ[а] из завейне чаше...» Нада у завичајни повратак није их напустила до последњег даха, мада су многи заувек остали у изгнанаству.

Циљ антологије (а и овог рада) је да «се зна да су ти људи постојали, да су им гробови остали у туђини, да [се врате] њихова имена у Србију коју су необично волели». ${ }^{9}$ Поред ових објављених поетских записа има још много тога уметнички записаног и израженог што сведочи о животу наше дијаспоре, а што није сабрано и објављено. То је саставни део српске културне и историјске баштине које се не можемо и не смемо тако лако одрицати јер шаље важне поруке и савременицима и будућим генерацијама. Овај рад је почетни корак у правцу осветљавања, признавања,

8 О наведеним стиховима преузетим из песмарице „Haga и ностиалїија» са страна 41-42 нема података да ли припадају некој конкретној песми.

9 А. Рељић у писму Р. Симовићу (Поговор збирке Наgа и носйалїја, Симовић, 2012:147). 
укључивања (али и рехабилитације) дела аутора из расејања са надом да је скренуо пажњу на њихов значај и вредност, јер неке од овде објављених песама својом изузетношћу заслужују да се нађу у свакој иоле репрезентативнијој антологији српске поезије 20. века.

\section{Литература}

Петров, А. (1994). Мање йознайи Дучић, A Less Known Dučić. Београд-Требиње-Питсбург. Сигнатуре

Поповић, Р. (2002). Изабрани човек или живой Расикка Пейровића. Београд. Просвета.

Симовић, Р. (2012а) (ур.). Наga и ностиаліија. Чикаго. Алекса Рељић, лично издање.

Симовић, Р. (2012b). Нaga и ностиалїја. Први предговор. Чикаго. Алекса Рељић, лично издање.

Jelena Lj. Vujić

Resume

\section{POETRY OF HOPE AND NOSTALGIA WRITTEN BY SERBIAN POST-WAR DIASPORA}

This paper focuses on the poetry written from 1940's to 1990's by the members of Serbian Diaspora living in the USA and Canada. Selected poems were published in a collection of poetry titled Nada $i$ nostalgija in 2012. The collection contains over 70 poems written both by established and renowned poets such as Jovan Dučić, Vojislav Ilić Mlađi, Nikolaj Velimirović or Rastko Peterović and poets amateures. Except for the likes of Dučić and Petrović, a considerable number of authors are little known to Serbian readers and literary critics. Most poems are written in modernist tradition though there are few which display postmodernist traits. We believe that in their artisitic and linguistic qualities many poems deserve to be included in Serbian literary heritage as they would contribute a great deal to it, which we support by appropariate literary study. The aim of this paper is to shed more light on the poetry of the Diaspora in an effort to rehabilitate and reinstate its authors and its status in the 20-century Serbian poetry.

Key words: poetry, patriotc poetry, hexameter, late patriotic cycle. 